\title{
Risk Management and Performance of Conventional Banks in Pakistan
}

\author{
ALAM REHMAN \\ NUML University Peshawar \\ alamrehmannuml@yahoo.com \\ YASIR KHAN \\ Ph.D Scholar, Qurtuba University Peshawar \\ yasirok62@yahoo.com \\ ARIF HUSSAIN \\ Assistant Professor, Abdul Wali Khan University, Mardan \\ arifhussain@awkum.edu.pk
}

\begin{abstract}
The study examines the relationship between risk management and performance of conventional banks in Pakistan. The study has been conducted using Capital adequacy ratio, non-performing loan ratio, Cost per loan ratio, Cash reserve ratio and Z-scoring ratio as the proxies of risk management and Return on asset has been used as the proxy of the bank financial performance. The study has used random sampling technique for the 20 conventional banks for the period 2010 to 2016. The study uses correlation and simple $O L S$ to test the hypothesis. The results reveal that capital adequacy ratio and Z-scoring have positive significant impact on the conventional banks, financial performance, where as Non-performing ratio, cost per loan ratio and cash reserve ratio predicting negative affect on the financial performance of the conventional banks in Pakistan. The study has practical as well as theoretical implications. The results are expected to help policy makers to rehash their policies by encompassing the approaches that facilitate the risk management of banks in Pakistan. The study will also help researchers in strengthening their level of understanding of these relationships. Replication of the study may help to validate the hypothesized model and their consequent application in the organizations that share somewhat similar organizational structures.
\end{abstract}

Key words: Risk management, conventional Banks, Pakistan, Correlation and Regression

\section{Introduction}

In the recent past the worldwide financial institutions witnessed a huge meltdown around the globe. This worldwide meltdown affected all types of industries especially the banking industry was suffered a lot. The banking industry especially Leman-Brothers and Bear Stearns were suffered and embrace even bankruptcy. This forces them to prepare a framework of tough regulations to better deal with the anger of the 
Public c(Valencia, 2010 ; Nocera, 2009). These financial crises were due to various means and were subject to various explanations. The utmost determining factor which got serious attention during this particular crises era was the risk management disclosure. It is therefore concluded that risk management is a significant tools, helping the trust of general public, shareholders and other stakeholders. Risk management helps a kind of transparency and reliability in the bank. Due to this emerging effect of risk management in banks, all banks are much more committed towards a significant framework of risk management to foster smooth return and stability. Every bank tries to provide framework of risk management to better deal with the public sentiments and the interest of shareholders and stakeholders. There are various reasons of failure in risk management, like the very limited role of risk management department while loans are being granted generously. So this make serious for the risk managers not having proper voice and loans are granted without them been on board and some time the lack of timely forecast make the issue of risk management in financial sector. This has resulted and compelled the risk managers to furnish and establish rules of risk management in order to avoid too much concentration on assets and to minimize the volatility of return. It has been noticed that worldwide global financial crises did not affected the Pakistan banking industry at all but it served as a wakeup call to the banks and all other financial institutions in Pakistan. The low exposure to such crises were due to simple instruments are being traded in the banking sector of Pakistan and banks do not have more liquidity as compared to the institutions in the developed world.

Pakistan is country where limited researches have been conducted in the area of risk management and mostly researchers found that risk management practices are very vital for the smooth functioning of the banks. In connection to the risk management Afsin (2010) argued that most daily operations which are performed in banks are risky by nature due to which banks need to have efficient risk management strategy to urgently implement it in dealing such risks. He asserted that non-performing loan ratio and cost per ratio has significant negative correlation with bank performance i-e ROA and ROE. Similarly, Mirakhor (2007) argued that strong risk management can help both private and public banks to minimize their risk exposure and such ability can improve the competitive ability in the market. He argued that NPL ratio has negative impact on the financial performance, thereby documenting that the more non-performing loans of a bank will have adverse impact on the financial performance of banks and also evidenced that capital adequacy ratio has positive significant impact on the financial performance of banks. Paola and Alessandra (2012) argued that risk management has positive impact on the profitability of the banks. Ali said (2013) argued that credit risk has negative impact on the financial performance of banks, while he found that operational risk has also negative correlation with financial performance of banks in Pakistan. In the line of the findings of above few authors, Selma et al (2013) also argued that NPL and cost per loan ration has negative significant impact on the profitability of banks. They argued that as these ratio increases it will have adverse impact on the profitability of banks. They found liquidity negatively associated with the firm profitability. In contrary to those who believe that NPL and cost per loan ratio have negative impact on profitability, Omer et al (2011) documented that NPL and Cash reserve ratio (CRR) have positive impact. 
The appetite to have credit from banks has increased, which need to develop a comprehensive strategy to better deal with credit dilemma in banks and to properly manage the associated risks more effectively and efficiently. The banks must need to develop an accurate balance between risk management and its growth through ensuring transparency and governance and formally regulating the credit been provided by bank. Due to the availability of new business avenues, there is probability of new risk too, which need to be handled and managed. Applying the above principle will improve asset quality and risk management practices of banks. The banks usually face risks in their operation, capital, liquidity and credit. The banks in developing countries always confronted with the credit risk, like increase in non- performing loans and provision for loss loan ratio foster problem for the policy makers of banks. Moreover the lack of capital (shortage of deposits) also pose problems for the banks decision makers. The bank also faces problems due to their liquidity as more liquidity would keep bank away from earning return and maximizing growth. So placing funds in appropriate avenues is always a serious challenge to the decision makers in banking sectors. So the element of bank risk is associated with its operation, capital, solvency, liquidity and credit. In Pakistan studies have not tested the Z-scoring ratio as a proxy of risk management. This study is unique in this regard and that the study uses very fresh available data like the data up to 2016.

Risk management in conventional banks, in Pakistan is a real challenge for the management and policy makers as Pakistan economy is very volatile economy and there is step competition in banks across the country. The banks also having different strategies in term of their information and shareholder disclosure which have somehow impact on the financial performance. Therefore a research need to be conducted to comprehensively analyzed the relationship of risk management factors with the banks financial performance. So the study is conducted to ascertain the kinds of risk associated with the conventional bank performance and to investigate the impact of risk management practices on the financial performance of the conventional banks in Pakistan.

\subsection{Research Questions}

1. What kind of risks is there in conventional banks in the banking sector of Pakistan?

2. What kind of relationship is there between risk management practices and financial performance of conventional banks in Pakistan?

\section{Literature Review}

Risk management is essential and vital in banking industry for significant performance. The stack holder trust required for corporate grown in general market and which is possible only by managing various risk (Afzin 2010). Li Yuqi (2007) conducted study analyzing the relationship of bank risk management practices and its profitability. The data was analyzed through simple Ordinary Least Square and he found that credit ratio and liquidity ratio has negative relationship with the bank profitability. The study further elaborate that risk management; set of Control and moderator variables like the GDP growth rate, inflation rate and interest rate can also significantly effect the performance of banking sector. Hakim and Neamie (2001) analyzed the impact of risk management on bank performance covering period of 1993-1999 using fixed effect random effect model. The results found that credit risk is positively correlated with bank 
profitability. In contrast some researchers indicate negative relation among these variables, like liquidity if increases will inversely effect the bank performance. The study further suggested that commercial banks need to allocate its fund more effectively and efficiently in all its business units and avenues.

Agyei and Dasah (2012) analyzed the impact of risk management, specially the credit risk practices on the financial performance of banks in Ghana, covering period of 2005-2009 using the Ordinary Least Square, resulting that credit risk is negatively correlated with bank profitability and liquidity ratio has negative but insignificant impact on the financial performance. A similar study was conducted by Kolade and Ojo (2012) and investigated the impact of risk management specifically credit risk and capital risk using the data of 11 year through regression. The study revealed that Non Performing Loan Ratio has negative but insignificant impact on the firm return on assets while capital adequacy ratio has positive significant effect on the firm return on assets. Ogboi and Unuafe (2013) also analyzed the relationship between the firm risk and financial performance. Their study found the inverse relation between Non Performing Loan and firm performance, indicating that as the non-performing loans tend to increase it directly reduce the financial performance. The study farther found that the cost loan ratio has insignificant negative impact on the financial performance of banks by using time series cross sectional data and the was analyzed through System of General methods of Moments(GMM), which considered to be the appropriate model in analyzing the cross sectional data. Funso (2012) also analyzed panel data covering the period of 2000-2010 by using ROA as the proxy of financial performance and the Non-Performing Loan to loan \& advances and loan loss provision(loan loss provision to classified loans). The results indicated that both these ratio have negative relationship with the bank financial performance.

Kithinji (2010) investigated the impact of credit risk management, comprised of Non-Performing loan to total loan ratio and loan loss provision of the credit risk and the liquidity ratio for the liquidity risk. The study found that these ratios as increase in size do not have any impact on the financial performance of Kenyan Commercial banks. The study used data from 2004 to 2008 and evidenced insignificant results for the credit risk management proxies and significant negative results for the impact of liquidity risk on the financial performance ratio. Similarly, Wanjohi (2013) also investigated the relationship of risk management and financial performance, the results evidenced very good risk management practices and found that the increase in these ratios do not have sufficient impact on the financial performance of banks by using panel data of five years covering the span from 2008 to 2012. Anguka (2012) conducted study analyzing the relationship of bank risk management practices and its profitability. The data was analyzed through simple OLS and also tested for fixed effect and random effect and found that credit ratio and liquidity ratio has negative relationship with the bank profitability. The study also evidenced that capital adequacy ratio has positive but insignificant relationship with the firm financial performance. This study analyzed the data of Microfinance banks in Kenya.

Ogilo(2012) analyzed the impact of risk management on the performance of commercial banks and found that there is some relationship between the credit risk 
management determinants exploring through CAMEL indicators like (Capital Adequacy, Asset Quality, Management Quality, Earnings and Liquidity) and the financial performance in these selected banks. The study revealed that CAMEL components like capital adequacy, asset quality, management efficiency and liquidity showed weak correlation with financial performance (ROE) whereas earnings were found strongly correlated. This study evidenced that such model can also be used representing the risk management of a bank. Similarly, Jackson (2011) also conducted study using the same CAMEL model as by Ogilo (2010), he also found similar results obtained by the previous researchers using the same CAMEL model. He argued that the same independent variables of the CAMEL model can be used as independent variables covering risk management of bank. On the other hand, Wangai and Gathogo (2012) conducted primary research using questionnaire and found that non-performing loans significantly effects the profitability of banks, especially micro finance banks. So it was conclude that risk management is very vital for the bank performance. The study also found that operational risk and capital adequacy risk can also affect the financial performance significantly.

\subsection{Theoretical Framework}

After the review of relevant literature, the following theoretical framework has been developed.

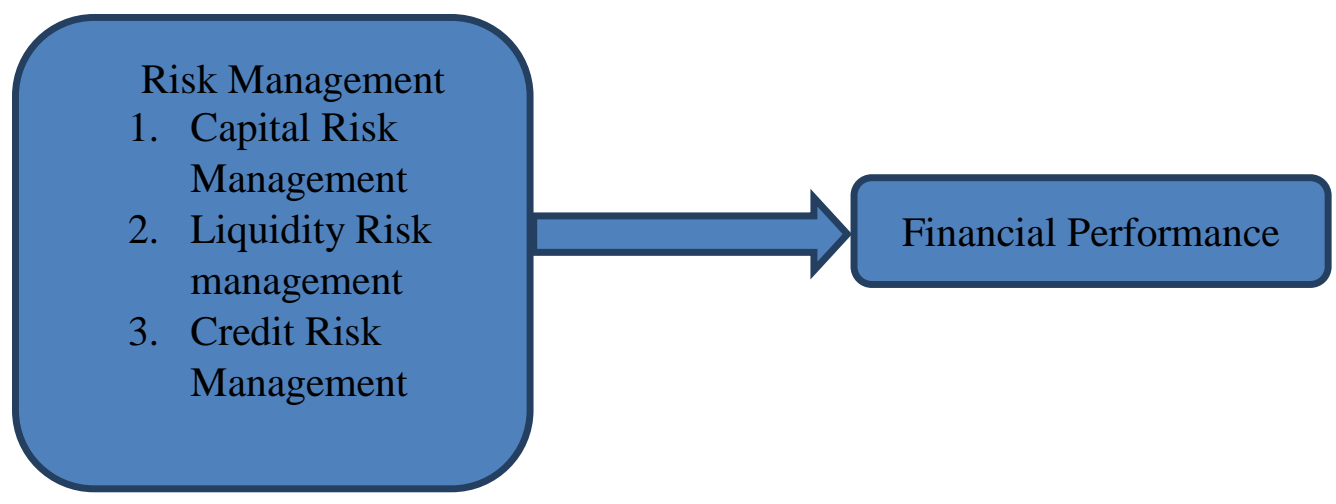

\subsection{Research Hypothesis}

\section{Figure1: Theoretical Framework}

The Research is based on the following research hypothesis.

H1: Capital adequacy ratio has positive significant impact on the financial performance of conventional banks in Pakistan.

H2: NPL ratio has negative significant impact on the financial performance of conventional banks in Pakistan.

H3: CLA has negative significant impact on the financial performance of conventional banks in Pakistan.

H4: Z-scoring ratio has positive significant impact on the financial performance of conventional banks in Pakistan.

H2: CRR ratio has negative significant impact on the financial performance conventional banks in Pakistan. 


\subsection{Operational Definitions and Measurement}

The study uses independent and dependent variables to test the hypothesis of this study. All these variables have been operationally defined and measured below.

\subsection{Independent Variables}

Following independent variables have been used in this study.

\subsubsection{Capital Risk}

Capital is very vital to any firm and has a greatest for shareholders. Capital ratio has been differently measured and calculated by different researchers, however in this research CAR has been measured as the bank's Tier1 cap+ Tier 2 capital/ total risk weighted assets.

\subsubsection{Credit Risk}

Credit plays a key role in bank's activities and asset portfolio. The high percentage and proportion of credit affect the bank's performance and is a serious concern to the managers in banking sector. The Non-Performing Loanratio (NPL), Cost per loan assets ratio (CLA) and Z-scoring ratio has been used as proxies of credit risk.

1. NPL $=$ Non performing loans/ total gross loans

2. $\mathrm{CLA}=$ operating cost/ total loan assets

3. $\mathrm{Z}$-score $=\mathrm{Z}=\mathrm{X}_{1}+\mathrm{X}_{2}+\mathrm{X}_{3}+\mathrm{X}_{4}+\mathrm{X}_{5}$.

$\mathrm{X}_{1}=$ Working Capital / Total Assets. .

$\mathrm{X}_{2}=$ Retained Earnings / Total Assets.

$\mathrm{X}_{3}=$ Earnings Before Interest and Taxes / Total Assets.

$\mathrm{X}_{4}=$ Market Value of Equity / Book Value of Total Liabilities.

$\mathrm{X}_{5}=$ Sales $/$ Total Assets.

\subsubsection{Liquidity Risk}

Liquidity is one of the key concerns to the managers in financial sector. Maintaining best level of liquid asset is always a challenge to the managers and the decision makers in banking sector. In this study cash reserve ratio will be used, and will be measured as the total cash/ Total deposits.

\subsection{Dependent variable}

Return on asset has been used as dependent variable of the study.

\subsubsection{Model Specification}

The following model has been used to test the hypothesis of the study. $\mathrm{ROA}_{i t}=\beta 0+\beta 1 \mathrm{CAR}_{\mathrm{it}}+\beta_{2} \mathrm{NPLR}_{\mathrm{it}}+\beta 3 \mathrm{CLA}{ }_{\mathrm{it}}+\beta 4 \mathrm{CRR}$ it $+\beta 5 \mathrm{Z}$-score it + it

\section{Research Methodology}

This is a quantitative research as the secondary data has been quantitatively quantified. The relationship between independent variables and dependent variable have been analyzed and investigated through correlation and regression analysis. The population of this study includes all conventional commercial banks listed on Pakistan stock exchange. Simple random sampling technique has been used for the data collection of this study. Those conventional banks have been included in the data collection which had existence in the banking sector since last five years. The data of 20 conventional has been collected for the period 2010 to 2016 . The data for the analysis of this study has been collected from the KSE web site, banks, annual reports and state bank site. 
The data was analyzed through statistical techniques i.e. Correlation and Regression analysis. Stata software has been used for the analysis of the data.

\section{Results and Discussion}

\subsection{Correlation Analysis}

The table 4.1 shows the results of the correlation of the study. The results indicate that Capital adequacy ratio is positively significantly correlated with the firm financial performance proxy, the return on Assets. This documents that as the value of this ratio increases it will increase the financial performance. The correlation results also reveals that NPL ratio is negatively significantly correlated with the financial performance of banks, which documents that increase in NPL ratio will enhance the financial performance of banks. Similarly cost per loan ratio and cash ratio also showing negative correlation with financial performance of banks but the severity it carries insignificant. It implies that an increase in the Cost per loan ratio and cash ratio will negatively affect the bank financial performance but the impact would not be Sevier due to the insignificant values. The results show a positive significant correlation between the Z-scoring ratio and financial performance. There by documenting that an increase in this ratio will enhance the bank's profitability.

\section{Table 4.1: Pearson Correlations analysis}

\begin{tabular}{|c|c|c|c|c|c|c|}
\hline Variables & ROA & $\begin{array}{l}\text { Capital } \\
\text { Adequacy } \\
\text { Ratio }\end{array}$ & $\begin{array}{l}\text { Non- } \\
\text { Performing } \\
\text { Loan Ratio }\end{array}$ & $\begin{array}{l}\text { Cost Per } \\
\text { Loan Assets }\end{array}$ & $\begin{array}{l}\text { Cash } \\
\text { Reserve } \\
\text { Ratio }\end{array}$ & $\begin{array}{l}\mathrm{Z} \text { - } \\
\text { score } \\
\text { ratio }\end{array}$ \\
\hline Return on Assets & 1 & & & & & \\
\hline Capital Adequacy Ratio & 0.233 & 1 & & & & \\
\hline Non-Performing Loan Ratio & $-0.284^{*}$ & -0.111 & 1 & & & \\
\hline Cost Per Loan Assets & $-0.031^{* *}$ & $-0.021^{* *}$ & 0.199 & 1 & & \\
\hline Cash reserve ratio & -0.0800 & $-0.021^{* *}$ & 0.024 & -0.130 & 1 & \\
\hline Z-score ratio & $0.324^{*}$ & $-0.419^{* *}$ & -0.196 & 0.129 & $-0.020^{* *}$ & 1 \\
\hline
\end{tabular}

\subsection{Regression Results}

Table 4.2 shows the effects of risk management proxies on the financial performance proxy of conventional banks in Pakistan. The results document a positive significant impact of the Banks's Capital adequacy ratio on the financial performance, as the tabulate T-value is 2.028 , which is significant at $5 \%$ probability level. The results also reported positive significant impact of Z-scoring ratio on the banks' return on assets, as the tabulated T-value of Z-scoring ratio is 2.908 , which is significant at $5 \%$ level of probability. The results show a negative significant effect of the NPL ratio on the banks, financial performance. The tabulated T-value is negatively significant at the 5\% probability level. However the results reported negative insignificant impact of Cost per loan ratio and Cash reserve ratio on the banks, return on assets. The explanatory power of the model is quite satisfactory as the R-square value tabulated is 0.58 , which documents that $58 \%$ changes in banks financial performance (ROA) is caused by the set of predicating variables of the study. The F- value is statistically significant at $5 \%$ 
probability level, which indicates that the overall model is fairly statistically fitted and significant. The muilticolinarity statistics show that there no muilticolinarity issue in the data. The tabulated values of tolerance and variance inflation factor (VIF) are within the acceptable ranges, thereby documenting that no muilticolinarity issue in the data of the study. As per Gujrati (2004) the value of VIF for a variable should not exceed 10, however the tabulated values of all explanatory variables are less than 2 , which predict non- existence of muilticolinarity in the data.

Table4.2: Regression Results

\begin{tabular}{|c|c|c|c|c|c|c|}
\hline \multirow[t]{2}{*}{ Variables } & \multicolumn{2}{|c|}{ Coefficients Std.Error } & \multirow[t]{2}{*}{ t-value } & \multirow[t]{2}{*}{ Sig. } & \multicolumn{2}{|c|}{ Collinearity Statistics } \\
\hline & & & & & Tolerance & VIF \\
\hline Capital Adequacy Ratio & .124 & 0.0611 & 2.028 & .014 & .623 & 1.786 \\
\hline $\begin{array}{l}\text { Non-Performing Loan } \\
\text { Ratio }\end{array}$ & -.121 & 0.0514 & -2.351 & .003 & .789 & 1.890 \\
\hline Cost per Loan Assets & -.098 & 0.0711 & -1.378 & .089 & .766 & 1.122 \\
\hline Cash Reserve Ratio & -.023 & 0.0262 & -.876 & .435 & .809 & 1.456 \\
\hline \multirow[t]{2}{*}{ Z-score Ratio } & .213 & 0.0732 & 2.908 & .001 & .755 & 1.498 \\
\hline & $\mathrm{R}^{2}=0.58$ & \multicolumn{2}{|c|}{ Adj. $R^{2}=0.57$} & \multicolumn{3}{|c|}{$\mathrm{F}=34.78 \mathrm{~F}($ sig. $)=.000$} \\
\hline
\end{tabular}

\section{Conclusion}

The study has been conducted with the aim to find and investigate the impact of risk management on the financial performance of conventional banks. The study has been conducted using Capital adequacy ratio, non-performing loan ratio, Cost per loan ratio, Cash reserve ratio and $\mathrm{Z}$-scoring ratio as the proxies of risk management and Return on asset has been used as the proxy of the bank financial performance. The study has used random sampling technique for the 20 conventional banks for the period 2010 to 2016. The final results have been predicted on the bases of simple OLS. The results revealed that capital adequacy ratio has positive significant impact on the banks, financial performance, which is in line with the findings of previous studies of $\mathrm{Li}$ and Zou (2014) and Alshatti (2015). However some previous studies evidenced a negative impact of CAR on the financial performance of firm, i.e Felix and Claudine (2008). The results reported negative significant impact of NPL ratio on the banks, return on assets. The same ratio was tested by Felix and Claudine (2008), Kargi (2011) and Omer et al (2011) who also have documented negative significant impact of NPL on the profitability of a firm. The results documented a negative impact of cost per loan ratio, which is line with the findings of Omer et al (2011) and Alshatti (2015). Similarly the study evidenced a negative insignificant impact of Cash reserve ratio on the financial performance of conventional banks. The results of CRR ratio are contrary to the findings of Afsin (2010) and Ali (2013), whom documented positive relationship of CRR with the financial performance. The results showed a positive significant impact of Z-scoring ratio on the 
financial performance. The ratio is an addition in the risk management studies in Pakistan and has not been tested before. The study has some policy implications. This study will help the decision makers and top management of the banking sector to overlook on these key areas of banks to tighten their policies and take remedial actions if they feel weaknesses in the practices of risk management. Similar studies can be conducted in future using moderating and mediating variables like GDP of a country, information disclosure and risk disclosure.

\section{References}

Adrian, T., \& Shin, H. S. (2010). Liquidity and leverage. Journal of financial intermediation, 19(3), 418.

Anguka, W. O. (2012). The influence of financial risk management on the financial performance of Commercial Banks in Kenya (Doctoral dissertation, University of Nairobi, Kenya).

Boahene, S. H., Dasah, J., \& Agyei, S. K. (2012).Credit risk and profitability of selected banks in Ghana. Research Journal of Finance and Accounting, 3(7), 6-14.

Omer, et al. (2011). Positive association with bank performance, liquidity risk (CRR) has positive impact. In Paper to be presented at the International conference (pp. 1$35)$

Fredrick, O. (2013). The impact of credit risk management on financial performance of commercial banks in Kenya. DBA Africa Management Review, 3(1).

Kolapo, T. F., Ayeni, R. K., \& Oke, M. O. (2012). Credit Risk and Commercial Banks, Performance in Nigeria a panel model approach. Australian Journal of Business and Management Research, 2(2).

Li, Y. (2007). Determinants of banks' profitability and its implication on risk management practices: Panel evidence from the UK in the period 1999-2006.

Mirakhor (2007). Introducing Islamic banks into conventional banking systems.

Kubai, D. K. (2016). The effects of non-performing loans on operational efficiency of commercial banks in kenya (Doctoral dissertation, University of Nairobi).

Musyoki, D., \& Kadubo, A. S. (2012).The impact of credit risk management on the financial performance of banks in Kenya for the period. International Journal of Business and Public Management, 2(2), 72-80.

Nti, G. (2016). Kumasi, Ghana (Doctoral dissertation, Department of Economics, Kwame Nkrumah University of science and Technology)

Salim, B. F., \& Bilal, Z. O. (n.a).The impact of liquidity management on financial performance in mani banking sector.

Wanjohi, J. G. (2013). The Effect of Financial Risk Management on The Financial Performance of Commercial Banks In Kenya (Doctoral dissertation, University of Nairobi). 